\title{
Post Mortem Examination of Barn owl in Bangladesh - A first case report
}

\author{
Das BC ${ }^{1^{*}}$, Das $\mathrm{S}^{2}$, Nath $\mathrm{BK}^{3}$, Parvez MA ${ }^{1}$, Hossain $\mathrm{S}^{4}$ \\ ${ }^{l}$ Department of Medicine and Surgery, ${ }^{2}$ Department of Pathology and Parasitology ${ }^{3}$ Department of Dairy and \\ Poultry Science, ${ }^{4}$ Student, Faculty of Veterinary medicine, Chittagong veterinary and Animal Sciences \\ University, Chittagong, Bangladesh.
}

[Received: June 21, Accepted: September 25, 2014]

\begin{abstract}
The present study was the first postmortem examination of a barn owl in Bangladesh. A female Barn owl weighing 450grams was brought to the Teaching Veterinary Hospital (TVH) at Chittagong Veterinary and Animal Sciences University (CVASU) by the forest department, Chittagong. The history of traumatic injury on left wing by an electric fan one day back was recorded. Clinical and radiographic examination revealed an open overriding proximal left metacarpal fracture and was decided for pinning to correct the fracture. Retrograde intramedullary pinning was performed and immobilized the wing by bandage. At postoperative day one, owl was found death and PM was performed to find out the actual clues. Gross postmortem examination revealed chalky whitish layer formed over the heart and liver which indicates pericarditis and perihepatitis. Hemorrhage in the left thigh muscle was also observed. Biochemical examination revealed salmonella organism in the samples of liver and heart. Histopathological examination found tissue changes in the suspected organs. In conclusion, it is revealed that the probable causes of death were inanition, pain shock, unfavorable environment and with salmonella infection.
\end{abstract}

Key words: Barn owl, Pericarditis, Perihepatitis, Radiographic examination, Postmortem examination.

\section{INTRODUCTION}

The Barn Owl (Tyto alba) is the diversely distributed species of owl, and one of the most widespread of all birds. It is also familiar to as Common Barn Owl, to distinguish it from other species in the barn owl family Tytonidae. These form one of two main lineages of living owls, the other being the typical owls (Strigidae). T. alba is found almost anywhere in the world except polar and desert regions, Asia north of the Alpide belt, most of Indonesia, and the Pacific islands ${ }^{[1]}$. As they are diverse in habitat and frequently come in close contact of human being and may become injured accidentally. Management of accidental wound and fracture is fastidious even though exact anatomical reduction may not be necessary in these flight birds; the restoration of a fully functional wing is very important for her normal flying, Obviously, the repair of wing bone fractures is a challenge ${ }^{[2]}$. There is much literature on the natural history, husbandry, and medicine of bird of prey but barn owl is in dusk. The most common diagnosed infectious diseases include bumble foot, aspergillosis, candidiasis, poxvirus, herpes virus, collibacillois and salmonellosis ${ }^{[3]}$. Postmortem examination can often reveal significant findings in birds and, in many cases, can help to establish an accurate diagnosis about the cause of death. For good results, a comprehensive history and fresh specimens are required ${ }^{[4]}$.

\section{CLINICAL REPORT}

A female Barn owl weighing 450grams was brought to the Teaching Veterinary Hospital (TVH) at
Chittagong Veterinary and Animal Sciences University (CVASU) by the forest department with the history of traumatic injury of left wing by an electric fan one day back.

On physical examination, the owl was dull, depressed, anorectic, hanging of affected wing, (Figure: 1) unable to fly and specific examination revealed open fracture in the wing (Figure: 2). The case was subjected to radiograph for the diagnosis of nature of fracture (Figure:3). Radiographic examination revealed overriding proximal metacarpal fracture and was decided for pinning. Retrograde intramedullary pinning was performed by small K-wire pin after proper aseptic preparation of the surgical area. After stabilizing the fracture bone, wing was immobilized by bandage. Postoperatively, antibiotic Gentamicin (Genacyn vet ${ }^{\circledR}, 10 \mathrm{ml}$ vial Square Pharmaceuticals Ltd., Bangladesh) @ 2.5 $\mathrm{mg} / \mathrm{kg}$ body weight $\mathrm{i} / \mathrm{m}$ injection, anti-inflammatory agent Ketoprofen $\left(\right.$ ketoflam $^{\circledR}, 10 \mathrm{ml}$ vial, Opsonin Pharma, Bangladesh) @ $1.5 \mathrm{mg} / \mathrm{kg}$ body weight i $/ \mathrm{m}$ injection and for energy supplement $25 \%$ dextrose saline were administered s/c respectively. After one day it was found death and PM was performed to find out the actual cause of death. Gross postmortem examination revealed chalky whitish layer formed in heart and liver (Figure:4) that indicated pericarditis and perihepatitis, hemorrhage inside of the left thigh muscle and measured the following parameters- liver ( L-3.4 cm, W-2.4 cm), spleen ( L-1.0 cm, W-0.5 $\mathrm{cm})$, heart $(\mathrm{L}-2.3 \mathrm{~cm}, \mathrm{~W}$ - base, $2.1 \mathrm{~cm}$, apex 1.0 $\mathrm{cm})$, proventiculus $(\mathrm{L}-2.1 \mathrm{~cm}, \mathrm{~W}-1.8 \mathrm{~cm})$, gizzard ( L-3.3 cm, W-2.6 cm). For further investigation and to improve the learning curve, collected samples were sent to the microbiology, pathology and 
parasitology department for bacteriological and histopathological examination.

In microbiology lab, liver and heart samples were cultured in Brilliant green agar and TSI agar medium that revealed salmonella species. Histo-pathological examination revealed diffuse necrosis of liver (Figure:5) where the hepatocytes mostly lost their nucleus, congested hepatic sinusoids and cellular infiltration (Figure:6), striking destruction of the hepatocytes with karyolysis (K) and fatty change (F) (Figure:7), necrosis and sloughing off of the proventricular epithelium, tissue debris in the lumen, Profuse reactive cell infiltration in the lamina propria of the intestinal tract (Figure:8).

\section{DISCUSSION}

The present study revealed the cause of death of a barn owl. Barn Owls are short-lived birds. Most die in their first year of life, with the average life expectancy being 1 to 2 years in the wild. In North America the oldest known Barn Owl in the wild lived to be 11 years, 6 months. In Holland, a wild barn owl lived to be 17 years, 10 months old. In England, a captive female barn owl was retired from breeding at 25 years old ${ }^{[27]}$. Deaths in the wild are usually a result from not having enough food or falling victim to larger birds of prey or as result of motor vehicle accidents. Little known about the significance of diseases in great horned owl population, thought individual case reports have been published describing several infectious, parasitic and neoplastic conditions ${ }^{[6-11]}$. There is a report of causing death a total of 74 cases (35 hawks and 39 owls). The probable causes of death were accidental injury (33 cases), shot/trapped (7 cases), raptor predation (5 cases), poison (3 cases), adverse environment factors (8 cases), others ( 2 cases) and unknown causes (16 cases) ${ }^{[12]}$. Parasitism or disease was not found in this study in any of 12 postmortem. There is a report of the diagnostic findings of 132 great horn owls in USA. Emaciation 42 cases $(32 \%)$ and trauma 35 cases $(26 \%)$ are the most frequent diagnostic finding followed by gunshot 12 cases $(9 \%)$ toxicoses 11 cases ( $8 \%$ ), electrocution 9 cases $(7 \%)$, infectious diseases 6 cases $(4 \%)$ and
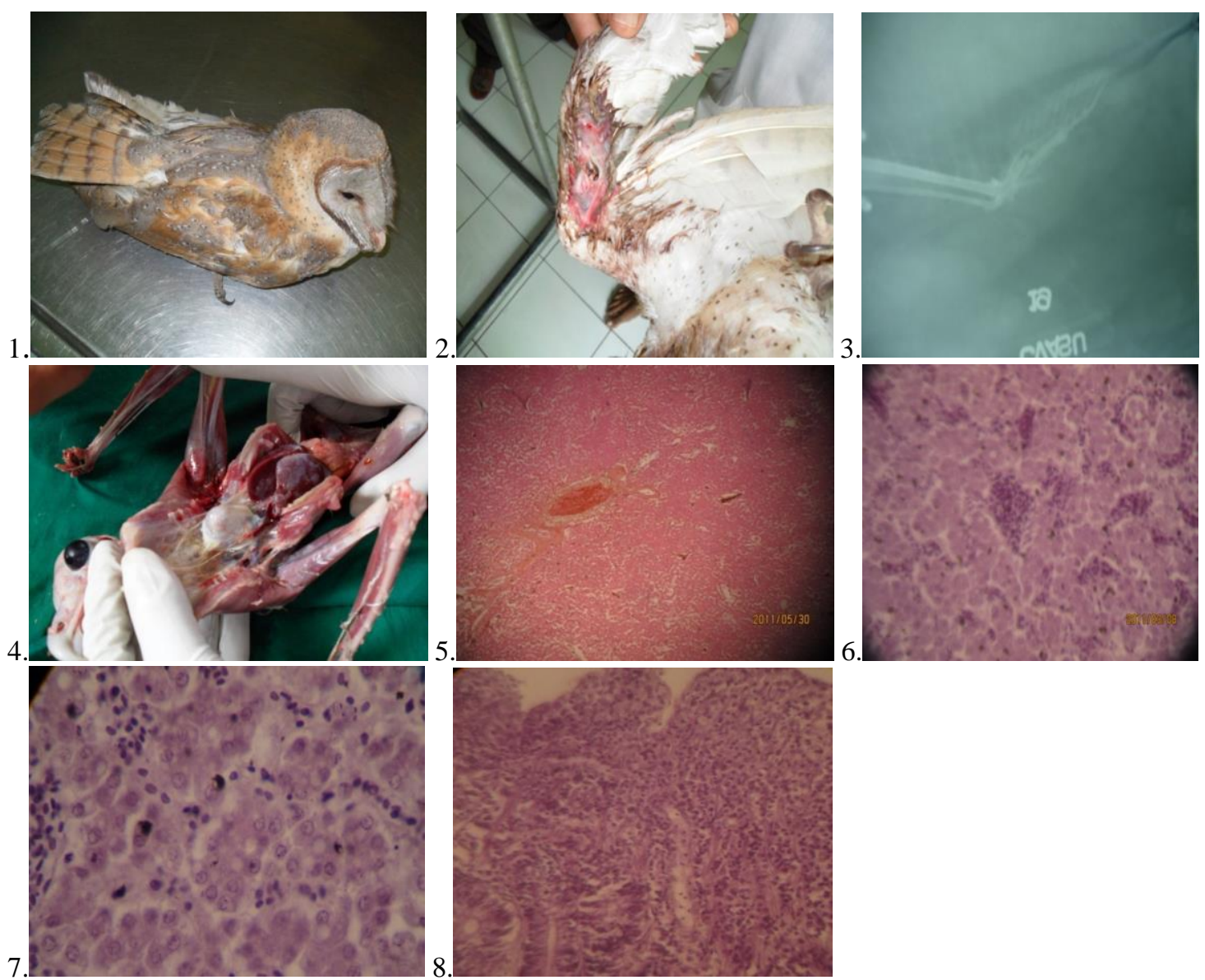

Fig 1: Dull and depressed Barn owl

Fig 2: Left open metacarpal fracture

Fig 3: X-ray revealed overriding proximal third metacarpal fracture

Fig 4: Chalky whitish layer formed over the heart and liver

Fig 5: Necrosis and dissociation of hepatic cords in liver section

Fig 6: Localized infiltration of reactive cells in the hepatic sinusoids

Fig 7: Karyolysis and loss of nucleus in the hepatocytes

Fig 8: Huge infiltration of reactive cells in the lamina propria of the small intestine; enteritis 
miscellaneous 3cases (2\%). No significant findings reported for 14 cases $(11 \%)$ carcasses ${ }^{[13]}$. The present case revealed the traumatic injury by fan and inanition since two days and unfavorable environment that were very similar to above findings.

Microscopic examination revealed salmonella organism in the heart and liver and histopathologic findings got some changes in the respected organs. Salmonellosis in wild and captive birds may be acute or chronic. Clinical signs are variable; acute disease manifestated by listlessness, excessive chirping, and occasionally diarrhea results in death in one to two days.

In older birds, septicemia are more common, and fribinous pericarditis, peritonitis, and congestion of lungs, kidneys, liver, and spleen occur ${ }^{[14]}$. Salmonella typhimurium, the serotype found in the majority of infected owls, and the same serotype was also the most commonly isolated from human and nonhuman sources from the United States in 1981, the most recent year for which data are available in CDC (1985) ${ }^{[15]}$. Salmonellosis in wild birds has been reported previously ${ }^{[16]}$, where multiple areas of focal necrosis were observed in liver lesions infected with Salmonella enterica Serotype Typhimurium. In some cases there may be necrosis in the large intestinal or cloacal mucosa ${ }^{[17]}$. Wild birds show characteristics multifocal areas of caseous necrosis and fibrinopurulent exudation in the crop or esophagus in cases of Salmonella Typhimurium infections. Therefore, our findings interrelate with the above described reports. Similar microscopic lesions are found in cases of Fowl typhoid; common bacterial disease in layer chicken caused by Salmonella enterica Serovar Gallinarum. Focal necrosis and degeneration with leukocytic infiltration in liver, pneumonic lesions in the lung and various degrees of catarrhal to hemorrhagic enteritis in the intestine are the characteristic findings of Salmonellosis in layer birds ${ }^{[18-20]}$. Salmonella spp. have been isolated from several orders of birds, particularly Charadriiformes and Passeriformes, but a few surveys have been reported of the Strigiformes [21]. There is a report of infection by Salmonella spp. in 94 nestling common barn-owls. Of 94 owls sampled by swabbing the cloaca, eight $(8.5 \%)$ were found to harbor Salmonella spp. Three serotypes- S. thompson, S. tutndorp, and S. typhimurium-were identified. Five $(20 \%)$ of the 25 nest sites examined contained Salmonella-positive owls ${ }^{[22]}$.

Isolation of $S$. gallinurum from a tawny owl (Strir aluco) has been reported ${ }^{[23]}$. There is a report of postmortem examination of common barn-owl in Pennsylvania, USA and opined that the owl's death was attributed to salmonellosis caused by $S$. typhimurium. Salmonella spp. were not detected in the postmortem examination of 10 little owls (Athene noctua) from Britain and Italy ${ }^{[24-25]}$; a longeared owl (Asio otus) and 20 common barn-owls (Tyto alba) from Britain; and 12 Tengmalm's owls (Aegolius funereus) and two Ural owls (Strir uralensis) from Norway. There was a report that prolonged, asymptomatic carriage of Salmonella can occur and that disease may be precipitated by stress [26]

This was the first postmortem examination of the owl in Bangladesh. The above discussions revealed that the probable cause of the death was multiple factors like inanition, pain shock and unfavorable environment with salmonella infection. Histopathological examination also enriched our practical knowledge in academic purposes.

Acknowledgments: The Author greatly acknowledges to the faculty members of the Dept. of Medicine and Surgery for their technical support.

\section{REFERENCES}

1. Bruce, M.D. (1999): Family Tytonidae (Barnowls). In: del Hoyo, J.; Elliott, A. \& Sargatal, J. (eds): Handbook of Birds of the World (Vol.5: Barn-owls to Hummingbirds): $34-75$, plates 13. Lynx Edicions, Barcelona.

2. Venugopal SK, Anoop S, Sarangom SB, Philip SB, Prakash S, Joy B, kankonkar AP. 2014. Repair and management of fractured wing in an indian peafowl (Pavo cristatus).

3. Deem SL. 2003. Fungal diseases of birds of prey. Vet. Clin. Exot. Anim. 6: 363-373

4. Gresham A and Ainsworth H. 2011. Avian practice: Postmortem examination of cage and aviary birds. 33 (7): 340-353.

5. Halliwell WH. Lesions of Marek's disease in a great horned owl. Avian Dis. 1971; 15: 49-55.

6. Keymer IF. Diseases of birds of prey. Vet. Rec.1972; 90: 579-594.

7. Sileo L, Carlson HC, S.C. Crumley. Inclusion body disease in a great horned owl. J. Wildl. Dis. 1975; 11:92 -96.

8. Kocan AA, Snelling J, Greiner EC. Some infectious and parasitic diseases in Oklahoma raptors. J. Wildl. Dis. 1977; 13: 304-306.

9. Clark, FD, Cinnah AD, Garner SA. Aspergillosis in a great horned owl (Bubo virginianus): a case report. Southwest. Vet. 1986; 37:11-12.

10. Swayne DE, Weisbrode SE. Cutaneous mast cell tumor in a great horned owl (Bubo virginianus). Vet. Pathol. 1990. 27:124-126.

11. Weir DN. Mortality of Hawks and Owls in Speyside, Bird Study. 1971; 18(3):147-154

12. Franson JC, Little SE. Diagnostic findings in 132 great horned owls. J. Raptor Res. 1996; 30(1):1-6

13. Locke, L.N., and Newman, J.A. Paratyphoid in a barn owl. Chesapeake Sci. 1970; 11:67

14. Centers for Disease Control. Salmonella surveillance data [memorandum]. Atlanta, Georgia. 1985, 1981; 26 pp.

15. Tizzard I. Seminars in avian and exotic pet medicine. 2004; 13(2): 50-66

16. Krickwood JK, Holmes JP, Macgragor S. Garden Bird Mortalities. Vet. Rec. 1995; 136 : 372 . 
17. Msoffe PLM, Minga UM, Mtambo MMA, Gwakisa PS, Olsen JE. Differences in resistance to Salmonella enterica serovar Gallinarum infection among indigenous local chicken ecotypes in Tanzania. Avian Pathol. 2006; 35: 270-276.

18. Deshmukh S, Asrani RK, Ledoux DR, Rottinghaus GE, Bermudez AJ, Gupta VK. Pathologic changes in extrahepatic organs and agglutinin response to Salmonella Gallinarum infection in Japanese quail fed Fusarium verticillioides culture material containing known levels of fumonisin B1. Avian Dis. 2007; 51: 705-712.

19. Ahmed AKM, Islam MT, Haider MG, Hossain MM. Seroprevalence and pathology of naturally infected salmonellosis in poultry with isolation and identification of causal agents. $J$. Bangl. Agri. Uni. 2008; 6: 327-334.

20. Steele JH, Galton MM. Salmonellosis. In Infectious and Parasitic Diseases of Wild Birds,
J. W. Davis et al. (eds.). Iowa State University Press, Ames, Iowa. 1971; 51-58.

21. Kirkpatrick $\mathrm{CE}$ and Bruce A. Colvin. Salmonella Spp. In Nestling Common BarnOwls (Tyto Alba) From Southwestern New Jersey. J. Wildl. Dis. 1986; 22(3): 1986. Pp. 340-343.

22. Wilson JE, Macdonald JW. Salmonella infection in wild birds. Br. Vet. J. 1967; 123: 212-219.

23. Goodchild WM, Tucker JF. Salmonellae in British wild birds and their transfer to domestic fowl. Br. Vet. J. 1968; 124: 95-101.

24. Modugno G, Ianeri A, Crincoli G. Richerche sulla presenza di salmonelle in volati selvatici catturati nell'italia meridionale. Acta Med. Vet. 1983; 29: 231-239.

25. Kapperud G, Rosef O. Avian wildlife reservoir of Campylobacter fetus subsp. Jejuni, Yersinia spp., and Salmonella spp. In Norway. Appl. Environ. Microbiol. 1983; 45: 375-380. 